
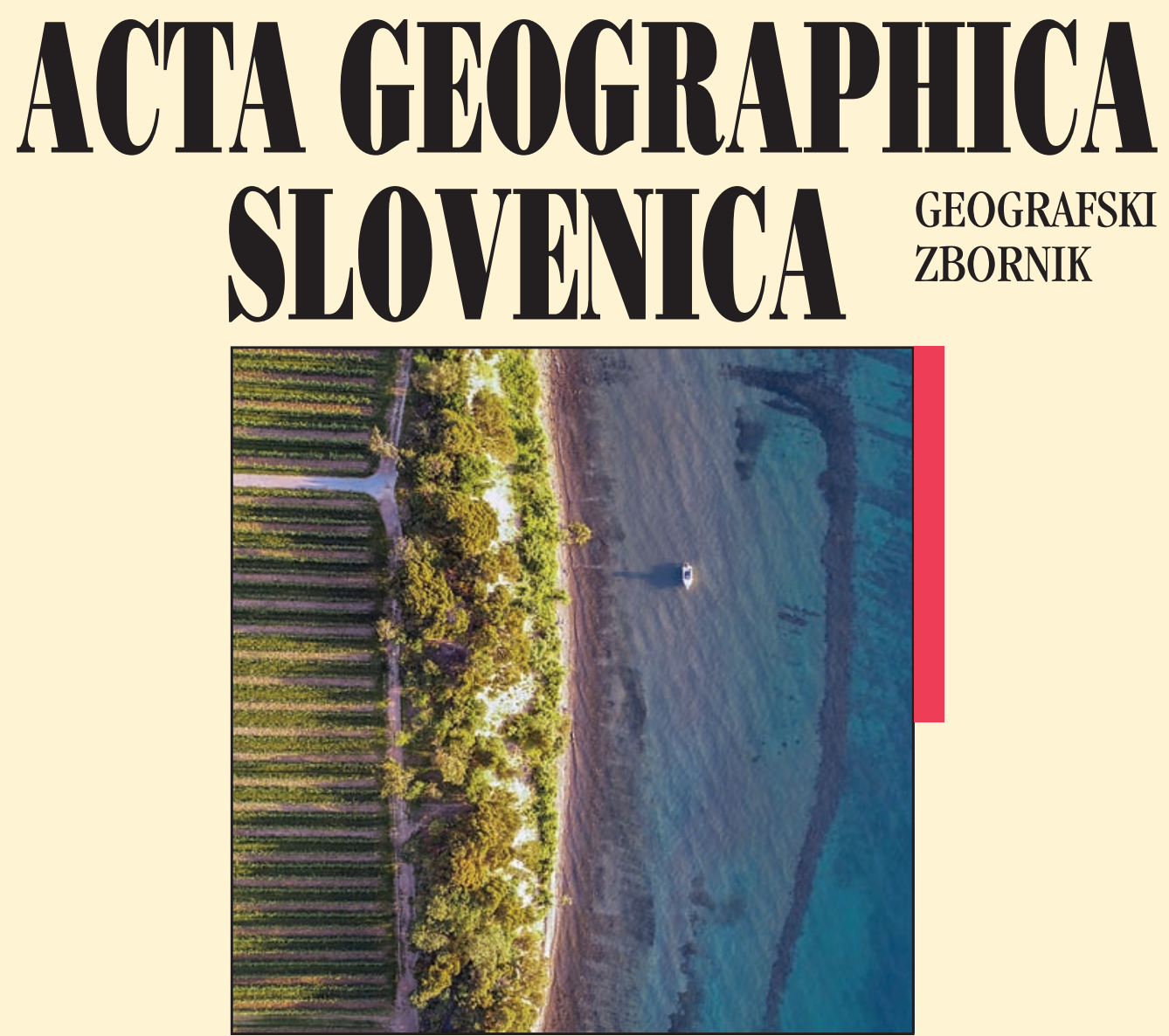


\section{ACTA GEOGRAPHICA SLOVENICA GEOGRAFSKI ZBORNIK 60-1 - 2020}

\section{Contents}

Mojca POKLAR

Comparison of the sonar recording method and the aerial photography method

for mapping seagrass meadows

Vanja PAVLUKOVIĆ, Uglješa STANKOV, Daniela ARSENOVIĆ

Social impacts of music festivals: A comparative study of Sziget (Hungary) and Exit (Serbia)

Péter János KISS, Csaba TÖLGYESI, Imola BÓNI, László ERDÖS, András VOJTKÓ, István Elek MAÁK, Zoltán BÁTORI

The effects of intensive logging on the capacity of karst dolines to provide potential microrefugia for cool-adapted plants

Radu SĂGEATĂ

Commercial services and urban space reconversion in Romania (1990-2017)

Kristina IVANČIČ, Jernej JEŽ, Blaž MILANIČ, Špela KUMELJ, Andrej ŠMUC Application of a mass movement susceptibility model in the heterogeneous Miocene clastic successions of the Slovenj Gradec Basin, northeast Slovenia

Andrej GOSAR

Measurements of tectonic micro-displacements within the Idrija fault zone in the Učja valley (W Slovenia)

Piotr RAŹNIAK, Sławomir DOROCKI, Anna WINIARCZYK-RAŹNIAK

Economic resilience of the command and control function of cities in Central and Eastern Europe

Mateja FERK, Rok CIGLIČ, Blaž KOMAC, Dénes LÓCZY

Management of small retention ponds and their impact on flood hazard prevention in the Slovenske Gorice Hills

\section{Gregor KOVAČIČ}

Sediment production in flysch badlands: A case study from Slovenian Istria

Vesna LUKIĆ, Aleksandar TOMAŠEVIĆ

Immigrant integration regimes in Europe: Incorporating the Western Balkan countries

Mitja DURNIK

Community development: Local Immigration Partnerships in Canada and implications for Slovenia

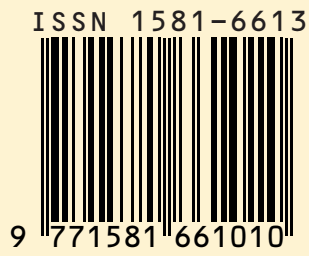




\section{APPLICATION OF A MASS MOVEMENT SUSCEPTIBILITY MODEL IN THE HETEROGENEOUS MIOCENE CLASTIC SUCCESSIONS OF THE SLOVENJ GRADEC BASIN, NORTHEAST SLOVENIA}

Kristina Ivančič, Jernej Jež, Blaž Milanič, Špela Kumelj, Andrej Šmuc

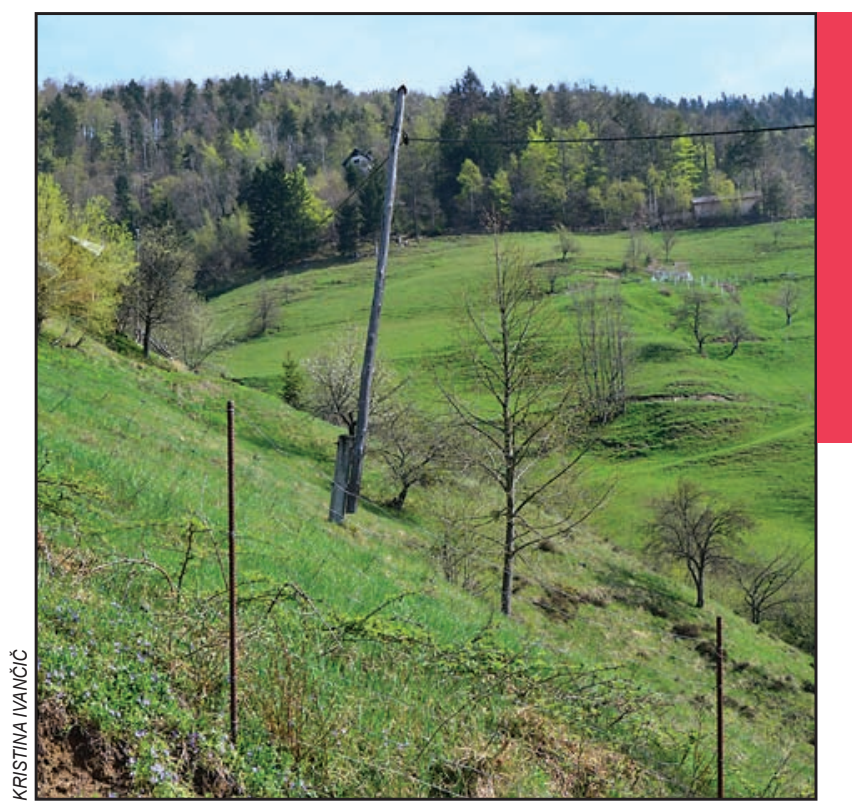

The hilly landscape between Slovenj Gradec and Velenje consists of soft sedimentary rock, which is susceptible to landslide formation. 
DOI: https://doi.org/10.3986/AGS.7040

UDC: 551.435.62:528.94(497.413)

COBISS: 1.01

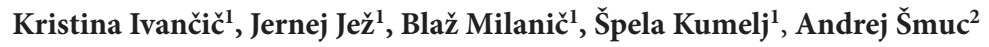

\title{
Application of a mass movement susceptibility model in the heterogeneous Miocene clastic successions of the Slovenj Gradec Basin, northeast Slovenia
}

\begin{abstract}
In Slovenia, mass movements are not only a threat to the population, but also a major environmental and social science challenge. Lithologically heterogeneous areas have been found to be problematic, and the Miocene Slovenj Gradec basin (in northeast Slovenia) is one such area. For this area, we developed landslide and rockfall susceptibility maps based on detailed geological research combined with statistical modeling schemes. Crucial factors include lithological composition, land use, geological structural elements, slope curvature, aspect and inclination, and bed dipping. The approach taken in the development of mass movement susceptibility maps presented here is transferable to other areas defined by heterogeneous lithology. Such maps could prove useful spatial planning, forestry, environmental protection, landscape architecture, and other fields.
\end{abstract}

KEY WORDS: Miocene, landslides, rockfalls, mass movement process modeling, heterogeneous lithology, Slovenia

\section{Model nevarnosti za pobočne procese na primeru heterogenih miocenskih zaporedij klastičnih kamnin v slovenjgraški kotlini v severovzhodni Sloveniji}

POVZETEK: V Sloveniji pobočni procesi ogrožajo prebivalstvo, hkrati pa so tudi velik okoljski in družboslovni izziv. S tega vidika so se za problematična izkazala litološko heterogena območja, med katerimi je tudi miocenska slovenjgraška kotlina v severovzhodni Sloveniji. Za to območje so avtorji na podlagi podrobnih geoloških raziskav v kombinaciji s shemami statističnega modeliranja oblikovali zemljevide nevarnosti za zemeljske plazove in skalne podore. Glavni dejavniki, ki vplivajo na oblikovanje tovrstnih procesov, so litološka sestava, raba tal, geološke strukturne prvine, ukrivljenost pobočja, ekspozicija, naklon in usmerjenost kamninskih plasti. Predstavljeni pristop k oblikovanju zemljevidov nevarnosti za pobočne procese je prenosljiv na druga litološko heterogena območja. Tovrstni zemljevidi bi bili lahko uporabni za področja, kot so prostorsko načrtovanje, gozdarstvo, okoljevarstvo in krajinska arhitektura.

KLJUČNE BESEDE: miocen, zemeljski plazovi, skalni podori, modeliranje pobočnih procesov, litološka heterogenost, Slovenija

The paper was submitted for publication on October $9^{\text {th }}, 2018$.

Uredništvo je prejelo prispevek 9. oktobra 2018.

\footnotetext{
${ }^{1}$ Geological Survey of Slovenia, Ljubljana, Slovenia

kristina.ivancic@geo-zs.si, jernej.jez@geo-zs.si,blaz.milanic@geo-zs.si, spela.kumelj@geo-zs.si

${ }^{2}$ University of Ljubljana, Faculty of Natural Sciences and Engineering, Department of Geology,

Ljubljana, Slovenia

andrej.smuc@geo.ntf.uni-lj.si
} 


\section{Introduction}

Mass movements are a very common geological phenomenon in Slovenia (Mikoš, Brilly and Ribičič 2004; Zorn and Komac 2008; Mikoš and Majes 2010; Zorn, Komac and Kumelj 2012). Their occurrence is related to diverse geological and tectonic structures, relief, and land use. They have caused considerable damage and occasionally threatened or even claimed human lives (Mikoš 2000/2001). In recent decades, geological phenomena including landslides, debris flows, and rockfalls have been intensively investigated in Slovenia (Mikoš et al. 2006; Mikoš, Fazarinc and Majes 2007; Zorn and Komac 2002, 2007, 2008, 2011; Jemec Auflič et al. 2017). Preventive measures have been identified as an important basis for avoiding damage and loss caused by mass movements and helping solve socioeconomic challenges. Among these measures, landslide susceptibility maps are a useful tool for minimizing potential hazard (Komac and Jež 2018) in terms of appropriate spatial planning based on the results of the investigations. Many susceptibility models for landslide zonation (Carrara et al. 1991, 1995; Guzzetti et al. 1999, 2006; Zorn and Komac 2007; Rossi et al. 2010; Petschko et al. 2014) and rockfall susceptibility zonation (Pannatier et al. 2009; Shirzadi et al. 2012; Böhme, Derron and Jaboyedoff 2014) have been used around the world. The methodology used in our research was developed as part of research projects at the Geological Survey of Slovenia (Bavec, Budkovič and Komac 2005; Komac and Jež 2018). It was developed using a linear model of weighted spatial factors tested by a univariate chi-square $\left(\chi^{2}\right)$ statistical method, which has already been utilized by several authors (Stančič and Veljanovski 1998, 2000a, 2000b; Veljanovski 1999; Komac 2005b). Initially, the methodology was used at smaller scales at the national level (Komac and Ribičič 2006), and later it was also applied to larger scales; that is, at the municipal and local levels. In order to verify the transferability of the methodology to other environments (also outside of Slovenia), it was tested on the example of the Municipality of Zvornik (Republika Srpska, Bosnia and Herzegovina), where it proved successful (Kumelj et al. 2014). The method was previously used for landslide and rockfall susceptibility zonation in the wider study area at a scale of 1:25,000. It turned out that approximately $70 \%$ of the area of the municipalities of Slovenj Gradec and Velenje are exposed to a medium, high, and very high occurrence of mass movement (Bavec et al. 2012a; 2012b).

In preparing the geological modeling input data, the most problematic areas were found to be areas with lithologically heterogeneous sequences. In such areas, rocks with different geomechanical properties alternate frequently within very short distances. Such rocks include Miocene and Permian-Carboniferous clastic sedimentary successions, which are most commonly found in central and northeastern Slovenia (Figure 1A). According to the Landslide Susceptibility Map of Slovenia, these are the most exposed hazardous landslide areas (Figure 1B). The problem of common occurrences of landslides in Neogene rocks in the wider Pannonian Basin was also addressed by Tošić et al. (2014).

This paper describes a possible approach in geologically diverse areas where detailed geological mapping and detailed geological profile logging constitute the main analytical tools. They provide more precise geological input data required for the model. The main purpose is to improve maps so that they are precise for large scales (e.g., 1:5,000), on which the susceptibility zonation for a specific location can be seen. The area between Podgorje (in the Municipality of Slovenj Gradec) and Gaberke was appropriate for our research because it is lithologically and morphologically heterogeneous with different land-use characteristics. The approach can be transferred to other areas with similar rock successions.

\section{Study area}

The investigated area is located between Podgorje (in the Municipality of Slovenj Gradec) and Gaberke in northeastern Slovenia, and it covers $11 \mathrm{~km}^{2}$ (Figures 1A, 2). The area studied is part of the Alpine macroregion and corresponds to the Eastern Karawanks, the Velenje and Konjice Hills, and the Strojna, Kozjak, and Pohorje mountains (Perko 1998). Paleogeographically, the investigated area is part of the Slovenj Gradec Basin and consists of alternating Miocene clastic sedimentary rocks.

The terrain in the study area is morphologically diverse. Only $3.6 \%$ of the study area has a slope less than $5^{\circ}$. In areas with steeper slopes, landslides could occur. A slope steeper than $38^{\circ}$ is found in $17.3 \%$ of the area and rockfalls can occur (Komac 2005a). Rarely, conglomerate and sandstone beds can even form overhanging walls. The highest point of the area reaches $825 \mathrm{~m}$, and the lowest is at $425 \mathrm{~m}$. The morphological diversity of the area is conditioned by the geological diversity there and, consequently, a branched 


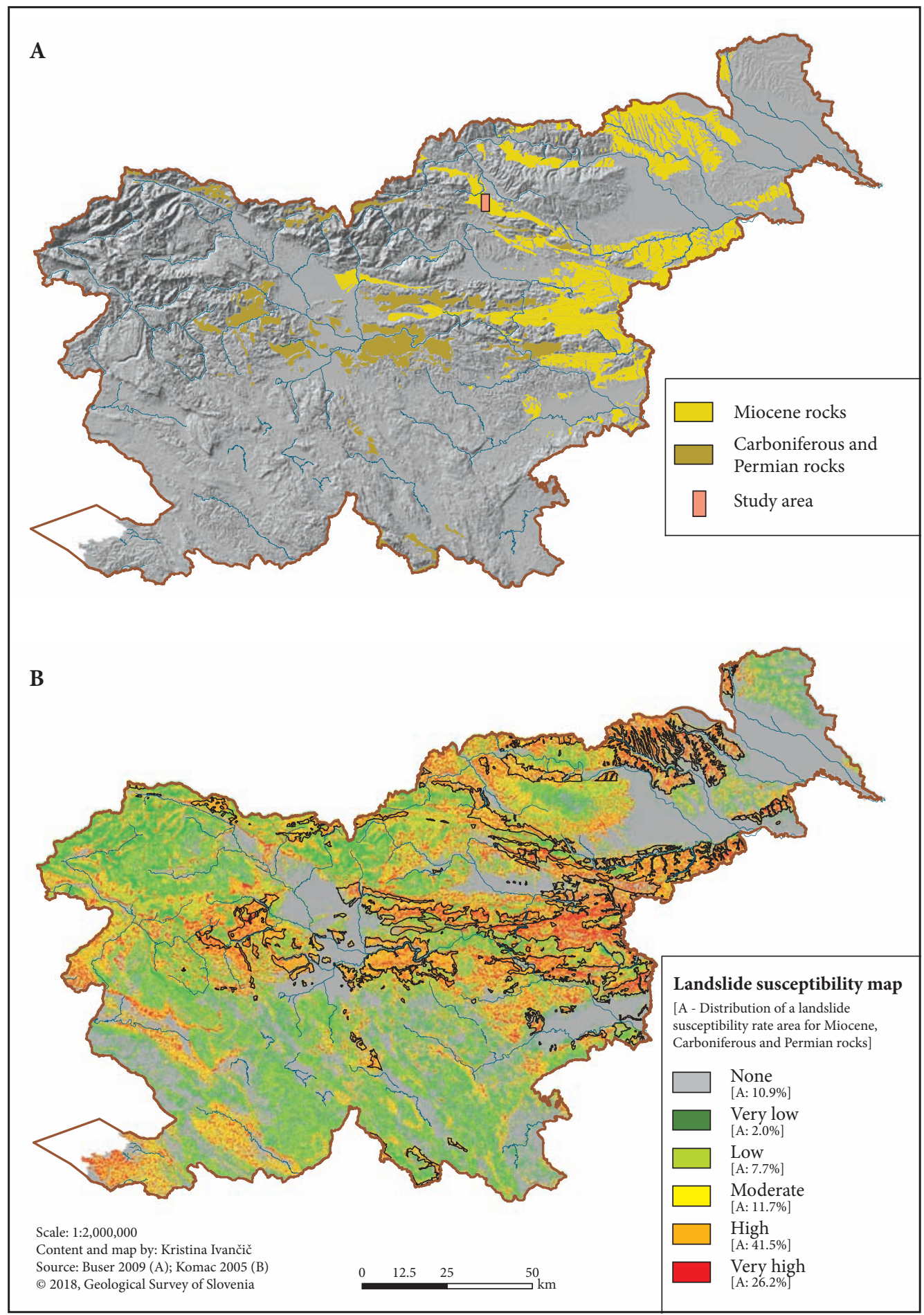

Figure 1: A) Areas with Miocene and Permian-Carboniferous clastic rocks, B) Iandslide susceptibility map of Slovenia (Komac and Ribičcic 2006). 


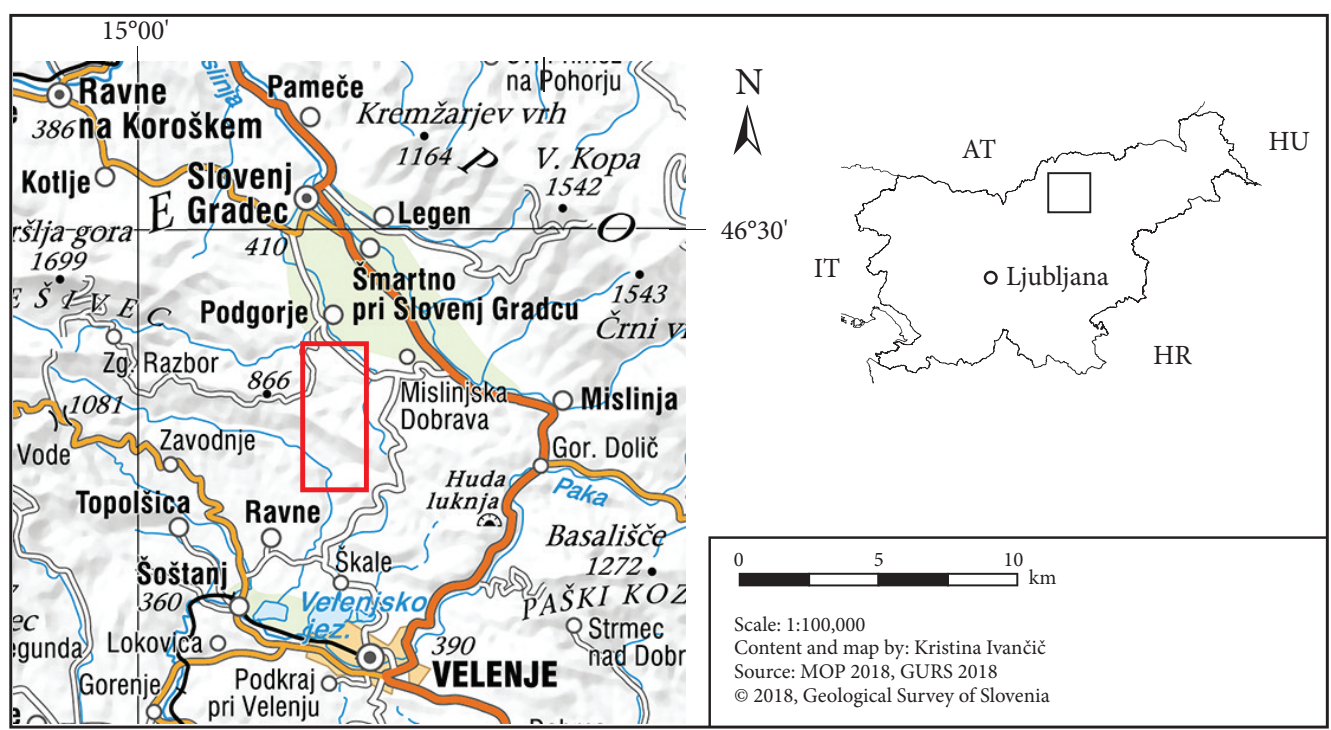

Figure 2: Topographic map with the location of the investigated area (red).

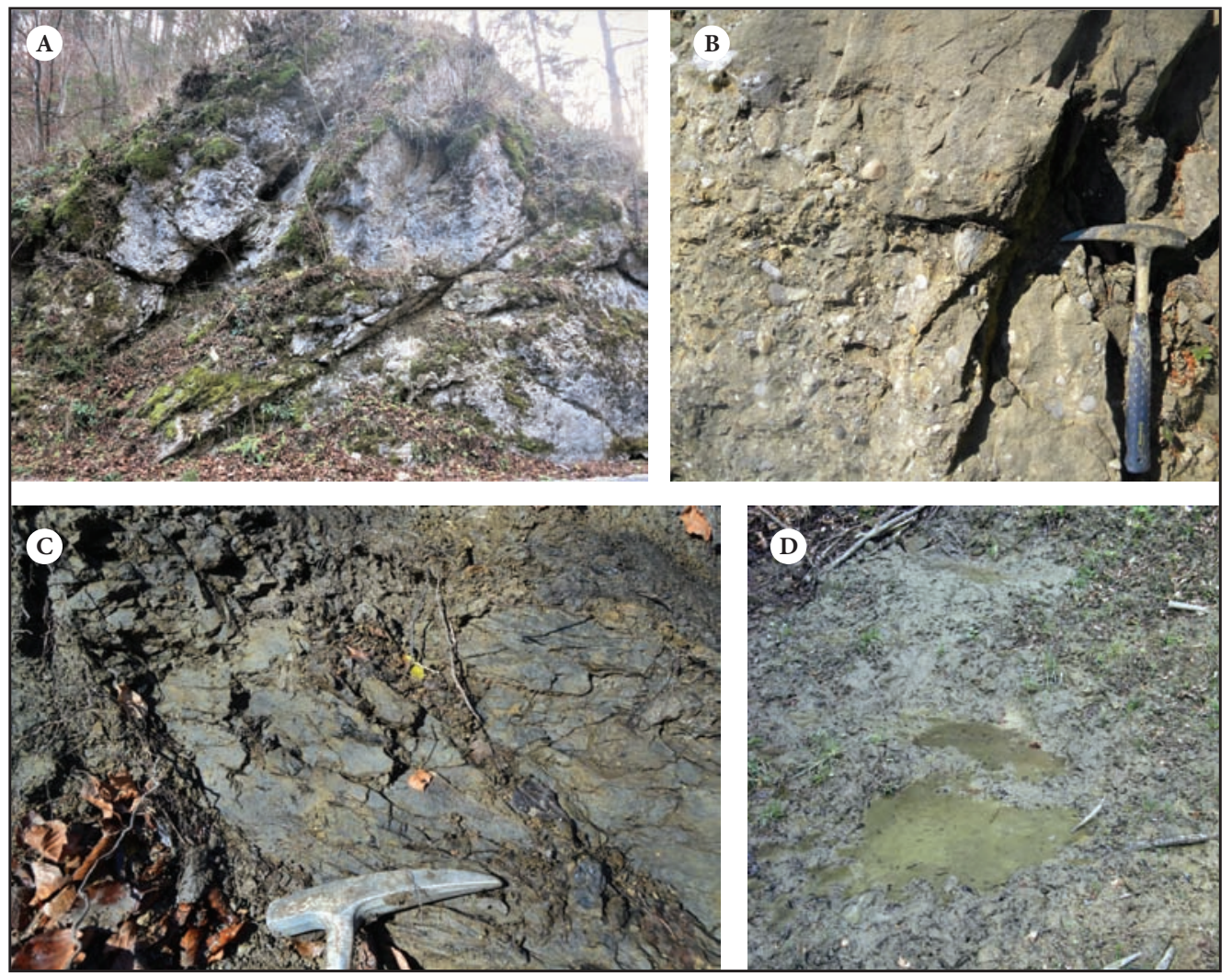

Figure 3: A) Cracks in conglomerate layers, B) alternation of conglomerate and sandstone layers, C) characteristic shaly marlstone, a consequence of weathering, D) water retention on impermeable claystone. 
river system of the torrent type. The main valleys and ridges formed in a northwest-southeast direction and are partly conditioned by the tectonic structure present there.

The investigated area is faulted and folded. Faults and fault zones are more frequent in the southern part of the area. They belong to the Periadriatic fault zone, which separates tonalite from clastic sedimentary rocks. Smaller-scale faults are present in other parts of the study area. In the entire investigated area, the rocks are fractured. The most prominent fractures are in the southern part of the area, occurring mainly in conglomerate (Figure 3A) and sandstone, and they are subordinate in siltstone.

In the area there are also two synclines and an anticline with a northwest-southeast axis orientation. The folding has resulted in variable dip of the beds, which ranges from 310-30/20-60 to 190-225/30-50.

\section{Methods}

Landslide and rockfall susceptibility models were developed for the area between Podgorje and Gaberke. The study is based on two primary types of data collection and processing schemes: a) geological mapping and sedimentological analyses, and b) the preparation of input data and statistical modelling.

\subsection{Geological methods}

Detailed geological mapping of rock outcrops was performed at a scale of 1:5,000 in order to obtain a detailed lithological map with geomechanical properties. In addition, tectonically fractured rocks, the location of faults and fault zones, and bed dip were evidenced, and a special focus was placed on existing landslides. Seven lithological sections present in different parts of the Slovenj Gradec Basin succession were recorded at a scale of 1:100 in order to precisely determine the type and properties of rocks (Figure 4A).

The lithological units were reclassified into six susceptibility categories according to landslide and rockfall susceptibility (Bavec, Budkovič and Komac 2005; Komac and Jež 2018), where Category 1 shows areas with no occurrence (area under $5^{\circ}$ ) and Category 6 shows areas that are very prone to mass movement event occurrence.

\subsection{Input data and statistical modeling}

Two existing conceptual models (a methodology for estimation of geohazard induced by mass movements; Komac 2003a, 2005a; Bavec, Budkovič and Komac 2005) were used to determine landslide and rockfall susceptibility rates. The method is explained in Komac (2003a, 2003b, 2005a) and Komac and Ribičič (2006). It was developed using a linear model of weighted spatial factors. Univariate statistical methods (the chisquare method) were used to test the influences of individual spatial factors on landsliding, and multivariate statistical methods were used to test the importance of individual factors in landslide occurrence. Komac (2005a) developed 3,142 models for landslide susceptibility and 7,674 for rockfall susceptibility using the Monte Carlo method. For the landslide model, lithological data are combined linearly with the synchronicity of the bed dips and the slope aspect, applying a weighting ratio of 0.8 for the lithological composition and 0.2 for the dip of the beds. In addition, land-use factors, distances from structural elements and fault zones, slope aspect, and curvature were all included. Precondition spatial-temporal factors for landslide occurrence are lithology 0.3 , slope inclination 0.25 , landcover type 0.25 , slope curvature 0.1 , distance to structural elements 0.05 , and slope aspect 0.05 (Figure $5 \mathrm{~A}$ ). For the rockfall model, lithological composition and fault zone parameters were weighted as follows: 0.5 for slope inclination, 0.35 synchronicity of dip of beds, and 0.15 for slope aspect weight (Figure 5B).

In general, the methodology of both models at a scale of 1:25,000 is based on four consecutive phases (Bavec, Budkovič and Komac 2005; Komac 2005a; Komac and Jež 2018): 1) synthesis of the existing cartographic archival geological data and verification fieldwork examinations in the phase map of geological hazards due to slope mass movements; 2) the production of a probability statistical model of geological 
Acta geographica Slovenica, 60-1, 2020

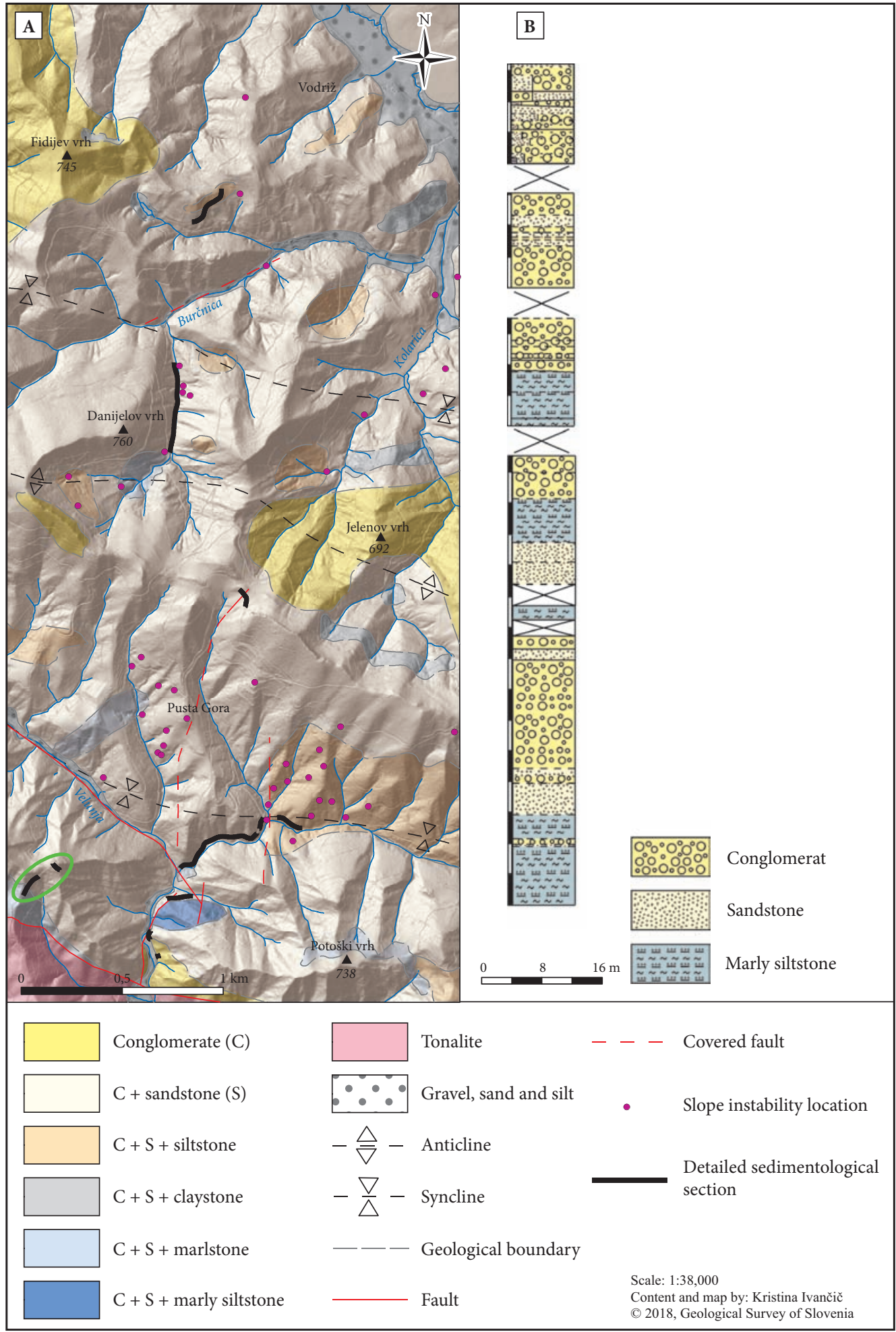




\section{A}

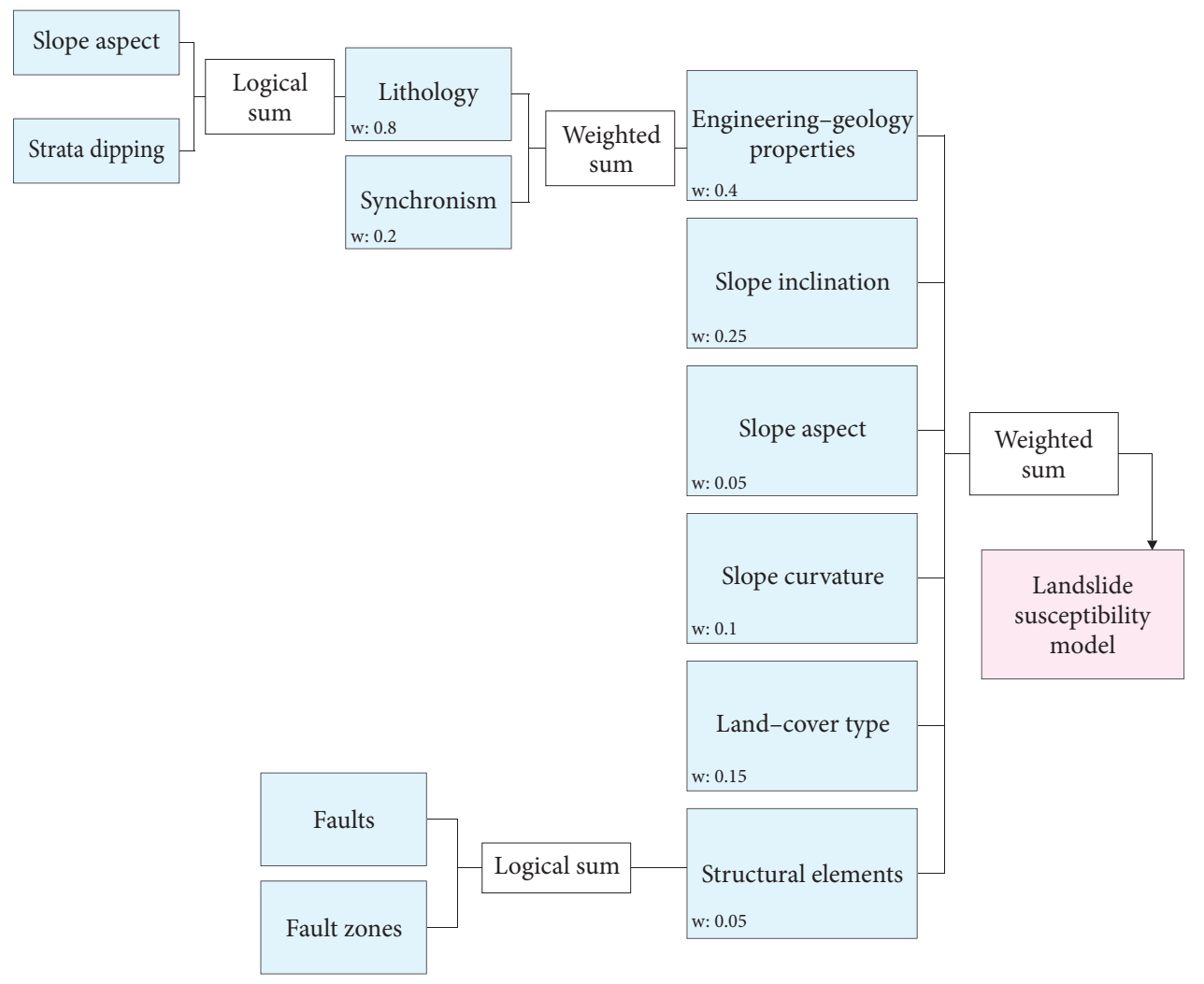

B

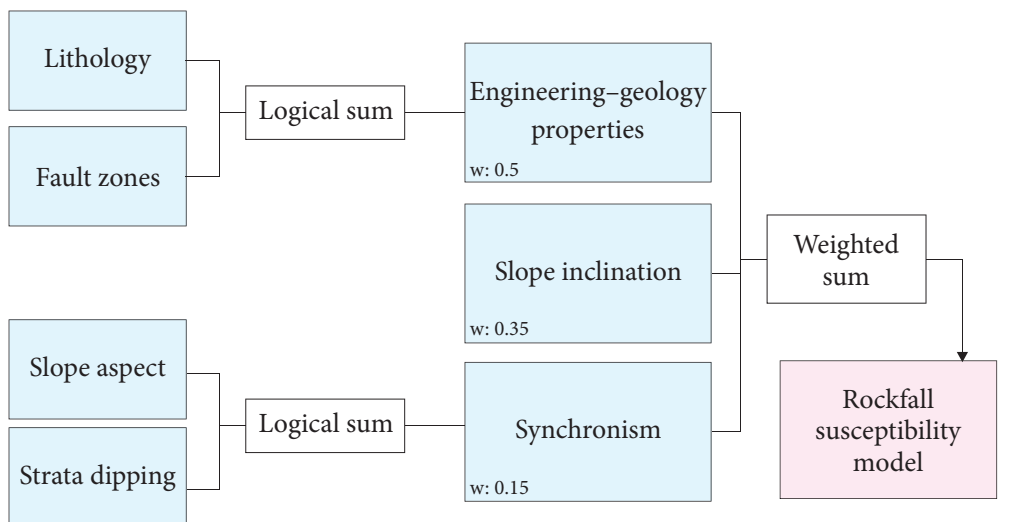

»W« stands for linear weight

Figure 5: A) Input parameters for the landslide susceptibility model, B) input parameters for the rockfall susceptibility model. 
hazards due to slope mass movements; 3 ) production of maps of geological hazards due to processes of slope mass movement based on the synthesis of Phase Map 1 and Probability Model 2 by exclusion of the most problematic areas, and 4) detailed mapping of more problematic areas at a scale of 1:5,000 or 1:10,000 and production of a detailed geological hazards map due to slope mass movements for these areas. In this paper, the modeling is based exclusively on new geological data, and therefore Phase 1 related to archival geological data is not included. The methodology starts with the process of Phase 4 .

Data on slope inclination, aspect, and curvature were derived from the digital relief model produced on the basis of LiDAR data at a spatial resolution of $1 \mathrm{~m}$ (MOP 2018). Areas under $5^{\circ}$ for landslides and areas under $38^{\circ}$ for rockfall are considered areas where the probability of landslide or rockfall is essentially zero, and they were therefore not included in the model (cf. Komac 2005a).

The values of the calculated models were classified into six landslide and rockfall susceptibility categories and were arranged according to changes in the distribution of frequency occurrence (Natural Breaks Jenks; natural boundary method). Class breaks are identified that best group similar values and that maximize the differences between classes. The features are divided into classes whose boundaries are set where there are relatively large differences in the data values (Esri 2006).

All landslides in the area studied from the national database (Komac and Hribernik 2015) were verified in the field, and new landslides identified during fieldwork were added to the database. This served as a basis for model validation. If the input parameters were identified as incorrect in the field (e.g., lithology or land use), we modified them accordingly in the model and ran a new one.

\section{Results}

\subsection{Lithological map}

The investigated area is composed of tonalite and alternation of conglomerate, sandstone, siltstone, marlstone, and claystone (Figure 4A). Tonalite is not part of the clastic sedimentary succession, and it is therefore not involved in our research. Conglomerate and sandstone predominate and were found throughout the entire investigated area. They frequently occur together, meaning that layers of sandstone alternate with conglomerate layers (Figure 3B). In general, more coarse-grained lithologies predominate in the northern part of the investigated area, whereas fine-grained intercalations and packages are more common in its southern part.

\subsection{Detailed description of lithological units}

Based on detailed fieldwork (Ivančič et al. 2018), all lithological units were defined and their geomechanical properties were evaluated. The frequent alternation of different lithological units could be well observed in the Gaberke section, where conglomerates, sandstone, and silty marlstone occur (Figure 4B).

Fine- to coarse-grained conglomerate is grain-supported, thin- to thick-bedded, or massive in places. The conglomerate is very well to poorly lithified, and sometimes fractured. It is present throughout the entire investigated area, and it is common in hilltops and ridges.

Fine- to coarse-grained sandstone is well to poorly lithified. The grains are bonded with carbonate and quartz cement, with a carbonate matrix. Sandstone was found throughout the investigated area, mostly in combination with conglomerate layers.

Siltstone occurs locally throughout the entire mapped area. It is laminated and bedded, and contains plant remains (Figure 3C). Although silty layers are usually present only in thin layers between sandstone and conglomerate beds, locally successions can be up to $32 \mathrm{~m}$ thick.

Marlstone and silty marlstone are frequently found on the southern part of the map, occurring in combination with conglomerate and sandstone. Marlstone is laminated and usually shaly, which contributes to its rapid weathering and poor geomechanical characteristics.

Claystone is mostly found in the northern part of the investigated area, occurring as thin layers in combination with conglomerate and sandstone. Retained water on the surface suggests impermeability of the unit (Figure 3D). 
Kristina Ivančič, Jernej Jež, Blaž Milanič, Špela Kumelj, Andrej Šmuc, Application of a mass movement susceptibility model ...

\subsection{Model}

The values of the final model (between 0 and 1) were classified into six landslide or rockfall susceptibility classes. The method determines the boundaries between groups of data that exhibit relatively large differences between pairs of adjacent values. The classes are not equally distributed (Figures 8 and 9).

\subsubsection{Landslide susceptibility model}

The landslide susceptibility model indicates that $19.9 \%$ of the investigated area exhibits a very high probability of landslide occurrence. A moderately high probability is exhibited by $22.7 \%$ of the area, and $44.3 \%$ has a relatively low to a very low probability of landslide occurrence. The greatest landslide hazard areas are Plešivec (Figure 6) and Vodriž (Figure 7). The areas coincide with the real state of nature. The very high landslide susceptibility class that characterizes the Plešivec area coincides with already identified landslide hazard areas. These relatively vast unstable areas are mainly limited to meadows and pastures, whereas in forests they are not common. Generally speaking, those more susceptible areas coincide with fine-grained sedimentary rocks (Figure 4A), such as siltstone, marlstone, and claystone. These locations are presented in Figure 8.

\subsubsection{Rockfall susceptibility model}

The rockfall susceptibility model indicates that $22.1 \%$ of the investigated area belongs to the class of very high susceptibility, and $28.6 \%$ of the area to moderate susceptibility. Locations where rockfall occurrence has been documented are rare. The highest possibility for their occurrence is on the northwest part, the central part, and the southwest part of the investigated area (Figure 9). The area is mostly composed of a conglomerate, subordinate sandstone. It is bound to vertical walls in places. The result presented by the model coincides with the real situation in nature. The locations of the susceptible areas are marked in Figure 9.

\section{Discussion}

With this approach, the mass movement susceptibility models of the rockfall and landslides proved to be very precise and gave a very good approximation of the natural state. This was proved by verification. The areas of highest landslides and rockfall susceptibility coincide with the actual state of nature even in the study area between Podogrje and Gaberke, where the lithology frequently alternates. Very high and high landslide susceptibility in the study area turns out to be on the meadows and pastures with siltstone, marlstone, or claystone as bedrock. Landslides from the national database and new landslides are located in the high and very high susceptibility areas. Moreover, new landslides were determined during the verification process. They are located in areas of high and very high probability for landslide occurrence. The model did not specify the correct landslide susceptibility zonation in the case of locally changed land use or in the case of newly changed land use that is not included in the modeling process. One specific landslide occurs in the area of deforestation (Figure 7C). In this case, the bedrock is composed of alternating sandstone and conglomerate. Rockfalls in the study area are subjected to the lithology of conglomerate with rare sandstone layers.

Many different models were used in the past (Carrara et al. 1991, 1995; Guzzetti et al. 1999, 2006; Zorn and Komac 2004, 2007; Rossi et al. 2010; Reichenbach et al. 2018) to produce mass movement susceptibility zonation. Such models usually do not precisely define susceptibility to slope mass movements in lithological heterogeneous areas. The problem of heterogeneous lithology has already been discussed

Figure 6: Examples of larger labile areas in the Plešivec region. A) The area below the Koližnik farm, B) the area near the Grah farmhouse, C) the area at the Grabnar farm. The locations of areas 6A to 6C are also indicated in Figure 8. p. 71

Figure 7: Examples of individual landslides in the investigated area. A) Landslide at the Petelanšek farm, B) cleanup of the landslide along the road toward the Pelc farm, C) newly formed landslide on the freshly deforested section along Vodriž (reek, with marked main scarp. The locations of areas $7 \mathrm{~A}$ to $7 \mathrm{C}$ are also indicated in Figure $8 .>$ p. 72

Figure 8: Landslide susceptibility map of the investigated area. Points $6 \mathrm{~A}, 6 \mathrm{~B}, 6 \mathrm{C}, 7 \mathrm{~A}, 7 \mathrm{~B}$, and $7 \mathrm{C}$ mark the locations of the photos in Figures 6 and 7 . $>$ p. 73 Figure 9: Rockfall susceptibility map of the investigated area. $>$ p. 74 


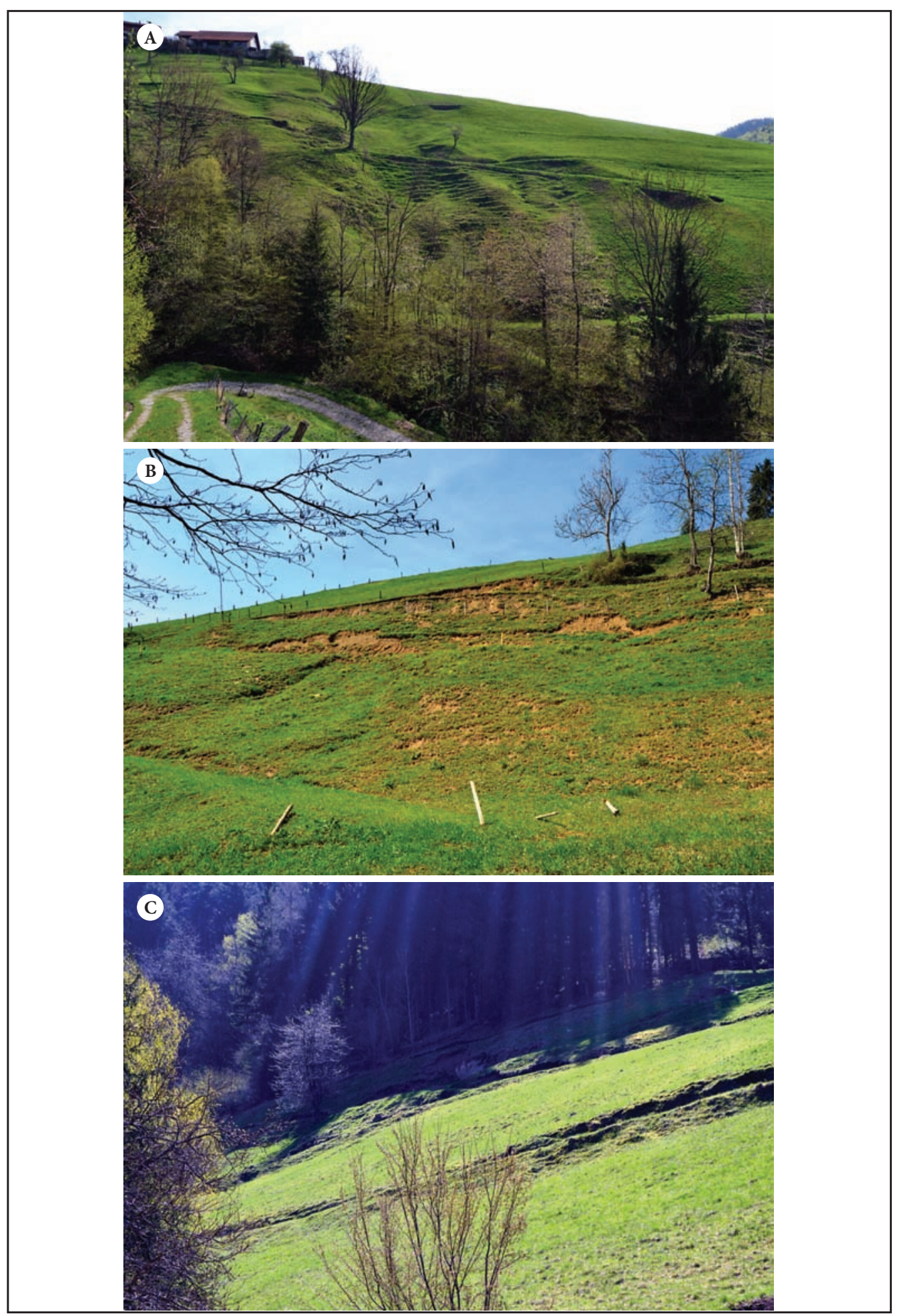




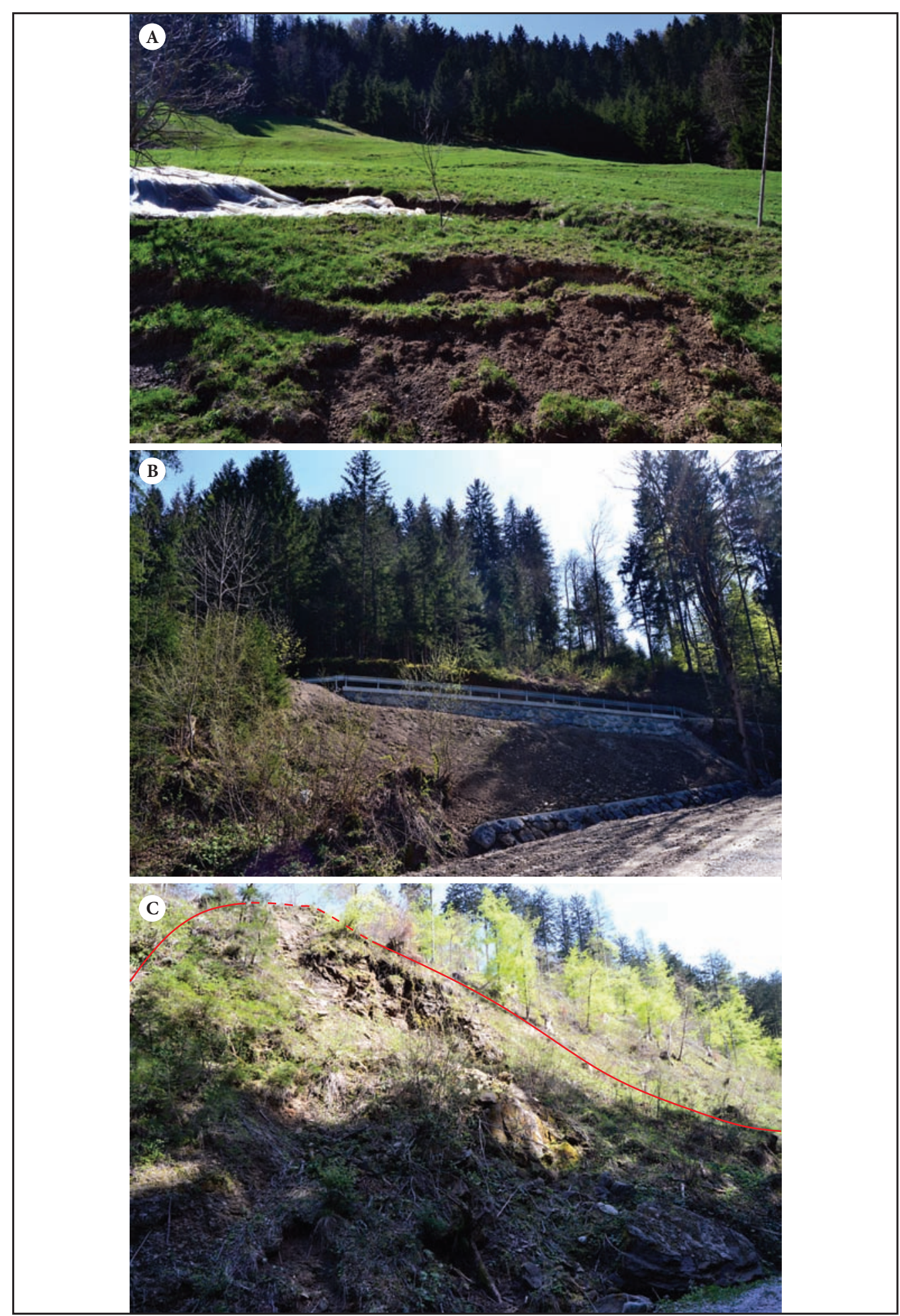




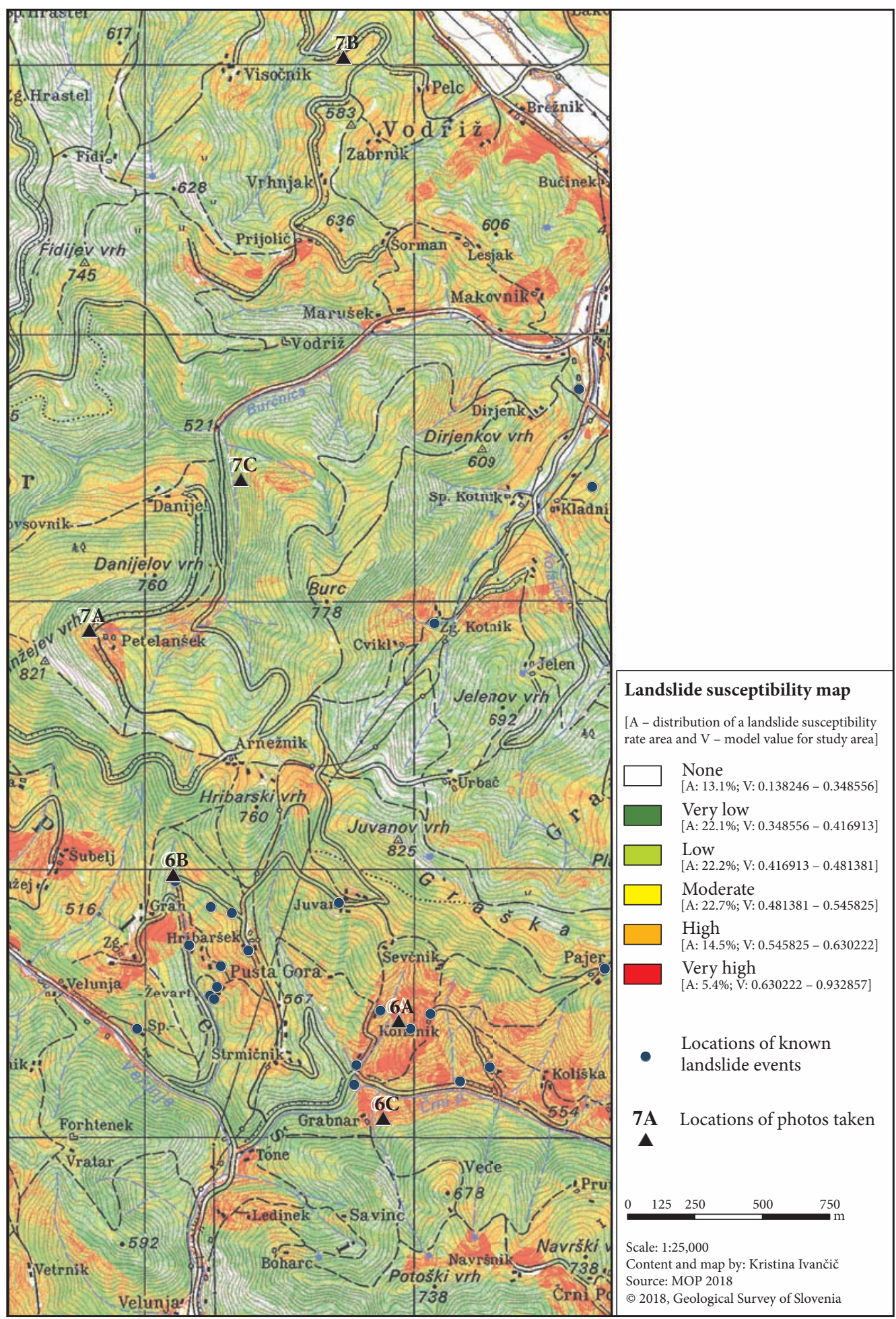




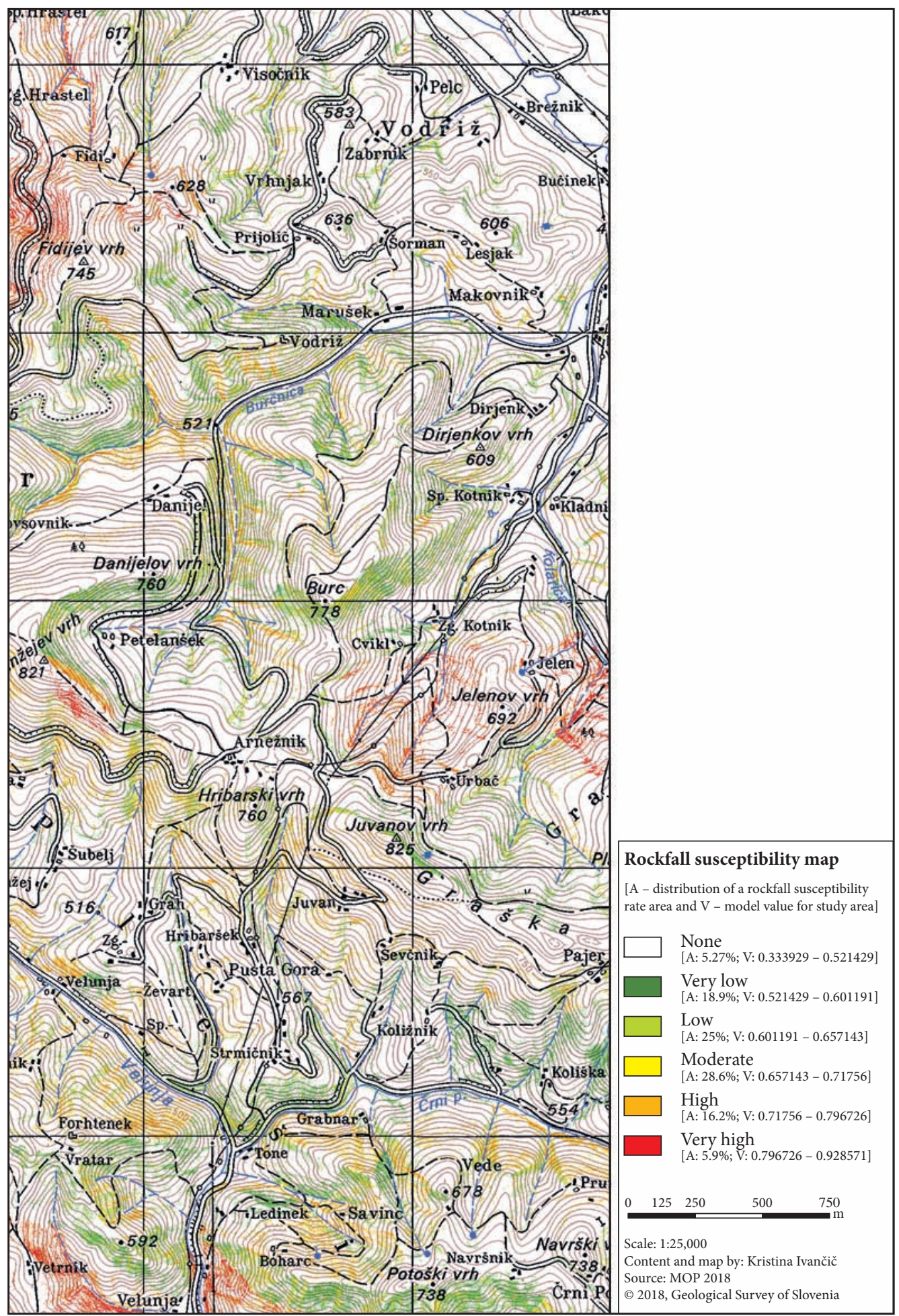


(Lee et al. 2008; Zorn and Komac 2009; Blahut, Van Westen and Sterlacchini 2010; Petschko et al. 2014). The greatest difference in our model is in its input factors, which are more precisely defined for slope (curvature, inclination, and aspect) and strata (dipping and aspect). Moreover, detailed mapping improves the input data of lithology and tectonic elements, and therefore the final landslide and rockfall susceptibility zonation is more detailed and usable at larger scales (e.g., 1:5,000). The model provides accuracy with respect to the worst-scale input parameter, but nevertheless more accurate data (such as LiDAR) show characteristic features that must be taken into account when interpreting the results. Geological maps at smaller scales (e.g., 1:100,000 or 1:25,000) usually do not sufficiently separate or differentiate lithologically heterogeneous units. Consequently, such maps are of limited use for mass movement susceptibility modeling.

The quality of the final predictions of the formation of slope mass movements primarily depends on the quality of the input geological data, and therefore it is necessary to combine the existing methodology of the modeling (Komac, Kumelj and Krajnik 2012; Bavec et al. 2012a, 2012b) with classic techniques of geological research (e.g., geological mapping and detailed recording of lithological sections). Only in this way can we obtain quality data, which, in combination with the geomorphological parameters of the terrain, make a significant contribution to the production of a useful final model of susceptibility to slope mass movements.

Today publicly available relief data (i.e., LiDAR data susceptibility) are significantly more accurate than that used by existing lithological maps, and this therefore contributes to more detailed geological fieldwork. In addition, current land-use data are also very important in the modeling process. Statistical data indicate that shallow landslides frequently occur in areas used as meadows, pastures, orchards, and vineyards (Komac 2005a). Certain factors related to changes in land use, such as deforestation and the cultivation of pastures and orchards, play a major role in the destabilization of labile areas (Fidej et al. 2018). Consequently, agricultural areas located in hazardous areas are often affected. Examples of such phenomena were also observed and documented in the investigated area. Determining the weighting ratio of the impact of the individual land use class (forest, vineyard, etc.) proves a particular challenge within the basic input factor: land use.

In addition to activities related to agriculture and forestry, the data in the model are indispensable in all spatial planning processes in the environment. Regional and local spatial planning and land use should be adjusted according to such models. It is worth mentioning that the models indicate source areas of potential mass movements, not their transport paths or deposition areas. As a rule, landslide deposition areas are generally not far from the landslide source, with the exception of cases in which large quantities of water are present, and the material can be converted into a mass (debris) flow. In the case of rockfalls, the material (blocks) may be deposited far from the source site (Zorn 2002).

\section{Conclusion}

Existing geological and pedological maps are not sufficiently accurate to produce quality detailed models, making it necessary to include precise field mapping and other basic geological research in the process. This is absolutely suggested in lithologically heterogeneous areas. A good example of this is the study area between Podgorje and Gaberke, where more than $40 \%$ of the area exhibits a very high, high, or moderate probability of landslide occurrence.

Alongside lithology, land use as model input factor (e.g., meadows and pastures, and deforestation) was found to be very important in the modeling process. In addition, changes in land use may play a major role in the destabilization of labile areas.

The susceptibility models presented here are sufficiently accurate and have been verified by checking known slope movement events in the investigated area. The approach used is transferable and comparable at all susceptibility levels, and it can be used in lithologically heterogeneous areas for large-scale maps $(1: 5,000)$.

The results can be used for spatial planning in the environment. By considering such models, the most hazard-prone areas can be avoided or can be dealt with in a geotechnically professional manner.

ACKNOWLEDGEMENT: This study was funded by the Slovenian Research Agency (ARRS) in the framework of the Young Researchers program, the Groundwaters and Geochemistry research program (P1-0020), 
and as part of research core funding no. P1-0011 (regional geology), which is carried out at the Geological Survey of Slovenia. We would like to thank Mladen Stumergar for preparation of samples for petrographic analysis. The authors are also grateful to Dragomir Skaberne and Matevž Novak for their generous help and support.

\section{References}

Bavec, M., Budkovič, T., Komac, M. 2005: Geohazard - geološko pogojena nevarnost zaradi procesov pobočnega premikanja. Primer občine Bovec. Geologija 48-2. DOI: https://doi.org/10.5474/geologija.2005.025

Bavec, M., Čarman, M., Krivic, M., Kumelj, Š., Požar, M., Komac, M., Šinigoj, J., Rižnar, I., Jurkovšek, B., Trajanova, M., Poljak, M., Celarc, B., Demšar, M., Milanič, B., Mahne, M., Otrin, J., Čertalič, S., Štih, J., Hrvatin, M. 2012a: Izdelava prostorske baze podatkov in spletnega informacijskega sistema geološko pogojenih nevarnosti zaradi procesov pobočnega premikanja, erozijskih kart ter kart snežnih plazov, Občina Velenje. Geološki zavod Slovenije. Ljubljana.

Bavec, M., Čarman, M., Krivic, M., Kumelj, Š., Požar, M., Komac, M., Šinigoj, J., Rižnar, I., Jurkovšek, B., Trajanova, M., Poljak, M., Celarc, B., Demšar, M., Milanič, B., Mahne, M., Otrin, J., Čertalič, S., Štih, J., Hrvatin, M. 2012b: Izdelava prostorske baze podatkov in spletnega informacijskega sistema geološko pogojenih nevarnosti zaradi procesov pobočnega premikanja, erozijskih kart ter kart snežnih plazov, Občina Slovenj Gradec. Geološki zavod Slovenije. Ljubljana.

Blahut, J., Van Westen, C. J., Sterlacchini, S. 2010: Analysis of landslide inventories for accurate prediction of debris-flow source areas. Geomorphology 119, 1-2. DOI: https://doi.org/10.1016/j.geomorph.2010.02.017

Böhme, M., Derron, M.-H., Jaboyedoff, M. 2014: Quantitative spatial analysis of rockfalls from road inventories: a combined statistical and physical susceptibility model. Natural Hazards and Earth System Sciences Discussions 2. DOI: https://doi.org/10.5194/nhessd-2-81-2014

Buser, S. 2009: Geološka karta Slovenije $1: 250.000$. Geološki zavod Slovenije. Ljubljana.

Carrara, A., Cardinali, M., Detti, R., Guzzetti, F., Pasqui, V., Reichenbach, P. 1991: GIS Techniques and statistical models in evaluating landslide hazard. Earth Surface Processes and Landform 16-5. DOI: https://doi.org/10.1002/esp.3290160505

Carrara, A., Cardinali, M., Guzzetti, F., Reichenbach, P. 1995: GIS technology in mapping landslide hazard. Geographical Information Systems in Assessing Natural Hazards. Dordrecht. DOI: https://doi.org/ 10.1007/978-94-015-8404-3_8

Esri. ArcGIS Desktop Help. ESRI, 2006.

Fidej, G., Mikoš, M., Jež, J., Kumelj, Š., Diaci, J. 2018: Presoja varovalnega učinka gozda pred drobirskimi tokovi. Gozdarski vestnik 76-4.

Guzzetti, F., Carrara, A., Cardinali, M., Reichenbach, P. 1999: Landslide hazard evaluation: a review of current techniques and their application in a multi-scale study, Central Italy. Geomorphology 31, 1-4. DOI: https://doi.org/10.1016/S0169-555X(99)00078-1

Guzzetti F., Reichenbach, P., Ardizzone, F., Cardinali, M., Galliet, M. 2006: Estimating the quality of landslide susceptibility models. Geomorphology 81, 1-2. DOI: https://doi.org/10.1016/j.geomorph.2006.04.007

Ivančič, K., Trajanova, M., Skaberne, D., Šmuc A. 2018: Provenance of the Miocene Slovenj Gradec Basin sedimentary fill, Western Central Paratethys. Sedimentary Geology 375. DOI: https://doi.org/10.1016/ j.sedgeo.2017.11.002

Jemec Auflič, M., Jež, J., Popit, T., Košir, A., Maček, M., Logar, J., Petkovšek, A., Mikoš, M., Calligaris, C., Boccali, C., Zini, L., Reitner, J., Verbovšek, T. 2017: The variety of landslide forms in Slovenia and its immediate NW surroundings. Landslides 14-4. DOI: https://doi.org/10.1007/s10346-017-0848-1

Komac, M. 2003a: Geohazard map of the central Slovenia - the mathematical approach to landslide prediction. Geologija 46-2.

Komac, M. 2003b: Landslide hazard prediction with analysis of satellite images and other spatial data. Ph.D. Thesis, University of Ljubljana. Ljubljana.

Komac, M. 2005a: Verjetnostni model napovedi nevarnih območij glede na premike pobočnih mas - primer občine Bovec. Geologija 48-2. DOI: https://doi.org/10.5474/geologija.2005.022

Komac, M. 2005b: Landslide occurrence probability prediction with analysis of satellite images and other spatial data. Geološki zavod Slovenije. Ljubljana. 
Komac, M., Ribičič, M. 2006: Landslide susceptibility map of Slovenia at scale $1: 250,000$. Geologija 49-2. DOI: https://doi.org/10.5474/geologija.2006.022

Komac, M., Hribernik, K. 2015: Slovenian national landslide database as a basis for statistical assessment of landslide phenomena in Slovenia. Geomorphology 249. DOI: https://doi.org/10.1016/j.geomorph.2015.02.005

Komac, M., Jež, J. 2018: TXT-tool 1-20 Landslide susceptibility assessment method. Landslide dynamics: ISDR-ICL landslide interactive teaching tools 1: Fundamentals, mapping and monitoring. Cham. DOI: https://doi.org/10.1007/978-3-319-57774-6_9

Komac, M., Kumelj, Š., Krajnik, M. 2012: Izdelava lokalnega/regionalnega načrta preprečevanja tveganj pred naravnimi in drugimi nesrečami za Severno Primorsko (Goriška statistična regija) za primer izbranih nesreč: (zemeljski) plazovi, poplave, potres, požar v naravi in ujma / burja. Geološki zavod Slovenije. Ljubljana.

Kumelj, Š., Jež, J., Milanič, B., Bavec, M. 2014: Zvornik municipality (Republika Srpska) - Landslide susceptibility map. Internal report on methodology, Geološki zavod Slovenije. Ljubljana.

Lee, C.-T., Huang, C.-C., Lee, J.-F., Pan, K.-L., Lin, M.-L., Dong, J.-J. 2008: Statistical approach to earthquake induced landslide susceptibility. Engineering Geology 100, 1-2. DOI: https://doi.org/10.1016/ j.enggeo.2008.03.004

Mikoš, M. 2000/2001: Značilnosti drobirskih tokov. Ujma 14-15.

Mikoš, M., Brilly, M., Ribičič, M. 2004: Landslides and floods in Slovenia. Acta hydrotechnica 22-37.

Mikoš, M., Brilly, M., Fazarinc, R., Ribičič, M. 2006: Strug landslide in W Slovenia: A complex multi-process phenomenon. Engineering Geology 83, 1-3. DOI: https://doi.org/10.1016/j.enggeo.2005.06.037

Mikoš, M., Fazarinc, R., Majes, B. 2007: Delineation of risk area in Log pod Mangartom due to debris flows from the Stože landslide. Acta geographica Slovenica 47-2. DOI: https://doi.org/10.3986/AGS47202

Mikoš, M., Majes, B. 2010: Mitigation of large landslides and debris flows in Slovenia, Europe. Landslides: Causes, types and effects. New York.

MOP - Ministrstvo za okolje in prostor: Geodetska uprava Republike Slovenije, Topografija: Javne informacije Slovenije. Ljubljana, 2018.

Pannatier, A., Oppikofer, T., Jaboyedoff, M., Stock, G. M. 2009: Rockfall susceptibility mapping of Yosemite Valley (USA) using a high-resolution digital elevation model. Geophysical Research Abstracts 11.

Perko, D. 1998: The Regionalization of Slovenia. Geografski zbornik 38.

Petschko, H., Brenning, A., Bell, R., Goetz, J., Glade, T. 2014: Assessing the quality of landslide susceptibility maps - case study Lower Austria. Natural Hazards and Earth System Sciences 14. DOI: https://doi.org/ 10.5194/nhess-14-95-2014

Reichenbach, P., Rossi, M., Malamud, B. D., Mihir, M. Guzzetti, F. 2018: A review of statistically-based landslide susceptibility models. Earth-Science Reviews 180. DOI: https://doi.org/10.1016/j.earscirev.2018.03.001

Rossi, M., Guzzetti, F., Reichenbach, P., Cesare, A., Peruccacci, M. S. 2010: Optimal landslide susceptibility zonation based on multiple forecasts. Geomorphology 114-3. DOI: https://doi.org/10.1016/ j.geomorph.2009.06.020

Shirzadi, A., Saro, L., Joo, O. H., Chapi, K. 2012: A GIS-based logistic regression model in rock-fall susceptibility mapping along a mountainous road: Salavat Abad case study, Kurdistan, Iran. Natural Hazards 64-2. DOI: https://doi.org/10.1007/s11069-012-0321-3

Stančič, Z., Veljanovski, T. 1998: Arheološki napovedovalni modeli in GIS. Geografski informacijski sistmi v Sloveniji. Ljubljana.

Stančič, Z., Veljanovski, T. 2000a: Understanding Roman settlement patterns through multivariate statistics and predictive modelling. Beyond the map. Washington.

Stančič, Z., Veljanovski, T. 2000b: Understanding Roman settlement patterns through multivariate statistics and predictive modelling. Geoarchaeology of the landscapes of Classical Antiquity. Leiden.

Tošić, R., Dragićević, S., Zorn, M., Lovrić, N. 2014: Landslide susceptibility zonation: a case study of the municipality of Banja Luka (Bosnia and Herzegovina). Acta geographica Slovenica 54-1. DOI: http://doi.org/10.3986/AGS54307

Veljanovski, T. 1999: Prostorsko modeliranje in napovedovanje lokacij arheoloških najdišč. B.Sc. Thesis, University of Ljubljana. Ljubljana.

Zorn, M. 2002: Rockfalls in Slovene Alps. Geografski zbornik 42.

Zorn, M., Komac, B. 2002: Pobočni procesi in drobirski tok v Logu pod Mangartom. Geografski vestnik 74. 
Zorn, M., Komac, B. 2004: Deterministic modeling of landslide and rockfall risk. Acta geographica Slovenica 44-2. DOI: https://doi.org/10.3986/AGS44203

Zorn, M., Komac, B. 2007: Probability modelling of landslide hazard. Acta geographica Slovenica 47-2. DOI: https://doi.org/10.3986/AGS47201

Zorn, M., Komac, B. 2008: Zemeljski plazovi v Sloveniji. Georitem 8. Ljubljana.

Zorn, M., Komac, B. 2009: The importance of landsliding in a flysch geomorphic system: The example of the Goriška brda hills (W Slovenia). Zeitschrift für Geomorphologie 53-2. DOI: https://doi.org/10.1127/ 0372-8854/2009/0053S3-0057

Zorn, M., Komac, B. 2011: Damage caused by natural disasters in Slovenia and globally between 1995 and 2010. Acta geographica Slovenica 51-1. DOI: https://doi.org/10.3986/AGS51101

Zorn, M., Komac, B., Kumelj, Š. 2012: Mass movement susceptibility maps in Slovenia: The current state. Geografski vestnik 84-1. 